\section{Gas Exchange and Growth of Two Transplanted, Field-grown Tree Species in an Arid Climate}

\author{
Thayne Montague ${ }^{1}$, Roger Kjelgren ${ }^{2}$, and Larry Rupp ${ }^{3}$ \\ Department of Plants, Soils, and Biometeorology, Utah State University, \\ Logan, UT 84322-4820
}

Additional index words. gas exchange, water deficit stress, leaf-to-air vapor pressure deficit, Norway maple, Acer platanoides, littleleaf linden, Tilia cordata

\begin{abstract}
Gas exchange and growth of transplanted and nontransplanted, field-grown Norway maple (Acer platanoides L. 'Schwedleri') and littleleaf linden (Tilia cordata Mill. 'Greenspire') trees were investigated in an arid climate. In the spring of 1995, three trees of each species were moved with a tree spade to a new location within a field nursery and three nontransplanted trees were selected as controls. Predawn leaf water potential, morning-to-evening stomatal conductance and leaf temperature, leaf-to-air vapor pressure difference, midday stomatal conductance and photosynthetic rate, and growth data were collected over a 2-year period. After transplanting, weekly predawn leaf water potential indicated that transplanted trees were under greater water stress than were nontransplanted (control) trees. However, predawn leaf water potential of maple trees recovered to control levels 18 weeks after transplanting, while that of transplanted linden trees remained more negative than that of controls. In 1995, stomatal conductance and photosynthetic rates were lower throughout the day for transplanted trees. In 1996, gas exchange rates of transplanted maple trees recovered to near control levels while rates for transplanted linden trees did not. Sensitivity of stomata to leaf-to-air vapor pressure difference varied with species and with transplant treatment. Each year transplanted trees of both species had less apical growth than did control trees. Although gas exchange and apical growth of transplanted trees was reduced following transplanting, recovery of gas exchange to control rates differed with species.
\end{abstract}

Field-grown (FG) trees lose a significant portion of their root systems (Gilman, 1988; Gilman and Beeson, 1996) and are subjected to great stress when transplanted. Water deficits often develop (Harris and Gilman, 1993; Kozlowski and Davies, 1975) because the natural balance between root absorptive area and transpiring leaf area is disrupted (Kramer and Kozlowski, 1979), and roots do not grow rapidly enough to absorb sufficient water to compensate for transpirational losses (Kozlowski, 1982). Because of increased wa-

\footnotetext{
Received for publication 25 May 1999. Accepted for publication 25 Oct. 1999. This research was supported by the Utah Agr. Expt. Sta., Utah State Univ., Logan. Approved as journal paper no. 7179. This paper represents a portion of the dissertation submitted by $\mathrm{T}$. Montague for the $\mathrm{PhD}$ in Plant Science at Utah State Univ. We thank David B. Wester for his statistical advice, and Ron Zollinger of Zollinger Fruit and Tree Farm for his support of this project. Mention of a trademark, proprietary product, or vendor does not constitute a guarantee or warranty of the product by Utah State Univ. and does not imply its approval to the exclusion of other products or vendors that also may be suitable. The cost of publishing this paper was defrayed in part by the payment of page charges. Under postal regulations, this paper therefore must be hereby marked advertisement solely to indicate this fact.

${ }^{1}$ Former Graduate Student. Current address: Dept. of Plant and Soil Science, Texas Tech Univ., Lubbock TX 79409-2122. E-mail address: thayne.montague@ttu.edu

${ }^{2}$ Associate Professor.

${ }^{3}$ Professor.
}

limited irrigation. To achieve this objective, we compared gas exchange and growth of transplanted and nontransplanted FG trees over a 2-year period.

\section{Materials and Methods}

Research was conducted in a commercial nursery located near Logan, Utah (U.S. Dept. of Agriculture hardiness zone 5a). In 1991, bare-root Norway maple and littleleaf linden trees were planted in a Kidman fine sandy loam soil (coarse-loamy, mesic, mixed Calcic Haploxeroll) in rows $9 \mathrm{~m}$ apart with $3 \mathrm{~m}$ between trees within the rows. Until the beginning of our experiment, irrigation and fertilization practices were consistent with commercial field nurseries in this area.

In Mar. 1995, six trees of each species (12 trees total) were selected for uniformity based upon a $5-\mathrm{cm}$ trunk diameter $15 \mathrm{~cm}$ above soil level. At transplanting, mean height was $5.1 \mathrm{~m}$ for maple trees and $3.7 \mathrm{~m}$ for linden trees. On 7 Apr. 1995, three trees of each species were selected randomly and moved with an 81-cm hydraulic tree spade (Vermeer Manufacturing Co., Pella, Iowa) to a new location within the original row. All trees conformed to the specifications of the American Association of Nurserymen Standards (American Standard for Nursery Stock, 1990). Planting holes were dug with the tree spade at the original tree spacing. Each hole was then enlarged to slightly larger dimensions than the root ball. After transplanted trees were placed into planting holes, two-thirds of the native soil was backfilled and trees were irrigated with $75 \mathrm{~L}$ of water. Soil was then placed around the root ball until soil level reached existing grade. Transplanted trees often receive limited irrigation (Gilman and Beeson, 1996; Harris et al., 1998); therefore, to simulate landscape conditions, $38 \mathrm{~L}$ of water was applied each week directly to the root ball area of transplanted and control trees. Throughout the study, trees were not pruned, weeds were removed by hand, and fertilizer was not applied. Each tree was selected randomly to remain in its original location, or to be moved to a new location within the original row. However, because of limited space, transplanted maple trees were near control trees, while transplanted linden trees were $\approx 15 \mathrm{~m}$ from control trees.

Six days after irrigation, weekly predawn $\psi_{\mathrm{L}}$ was measured at 0600 HR (Mountain Daylight Time) on two randomly selected, mature leaves from each tree. Leaves were excised before dawn, immediately sealed in a plastic bag, and placed in a cooler (Karlic and Richter, 1979). Water potential was measured within a half-hour of excision with a pressure chamber (model 3005; Soilmoisture Corp., Santa Barbara, Calif.). The six measurements for each species-treatment combination were averaged. Morning-to-evening measurements of leaf temperature (TL) and stomatal conductance $\left(g_{\mathrm{s}}\right)$ were performed on 21 and 27 July, and 9 and 23 Aug. 1995, and on 1 and 29 Aug. 1996. TL was measured with a hand-held infrared thermometer (model 210ALCS; Everest InterScience, Fullerton, Calif.) and $g_{s}$ was 
measured with a steady-state porometer (model 1600; LI-COR, Lincoln, Nebr.). Measurements began near 0900 HR. For data collection purposes, single trees of each species and treatment were paired. Measurement cycles began on the first pair of linden trees and continued on the first pair of maple trees. Cycles were repeated until all trees were measured. About a half-hour after the final measurement, the cycle was repeated. Data were recorded for four, fully expanded, mature, full-sun leaves, and two, fully expanded shade leaves on each tree, using different leaves during each cycle. Data collection ceased $\approx 1800$ HR. Data for each tree were recorded seven to nine times on each day of measurement. Stomatal conductance and $T_{L}$ for each cycle were taken as the means of 18 measurements for each speciestreatment combination.

On five dates (11, 21,30 Aug. 1995, and 15 and 22 Aug. 1996) midday leaf photosynthetic rate $(\mathrm{Pn})$ and $g_{\mathrm{s}}$ were measured between 1300 and $1500 \mathrm{HR}$ with a portable photosynthesis system (model 6200; LI-COR) in closed mode (Mitchell, 1992). Measurement cycles were as described above for measuring $g_{s}$; however, data were recorded once for each tree. For each tree, three different, fully expanded, mature, full-sun leaves were measured, and three observations were taken on each leaf. Midday Pn and $g_{\text {s }}$ for each species-treatment combination was taken as the mean of 27 measurements.

Climatic data were continuously collected by a weather station $\approx 8 \mathrm{~km}$ away. Incoming short wave radiation ( $\mathrm{S} \downarrow$ ) was measured with a pyranometer (model LI-200SA; LI-COR). Air temperature $\left(\mathrm{T}_{\mathrm{A}}\right)$ and relative humidity $(\mathrm{RH})$ were measured with a combination temperature and humidity sensor (model CR500; Campbell Scientific, Logan, Utah). All sensors were scanned every $10 \mathrm{~s}$ and averages were recorded every $30 \mathrm{~min}$ with a data logger (model CR10×; Campbell Scientific). LVPD was calculated using saturated vapor pressure at TL and ambient vapor pressure (Jones, 1992).

Prior to budbreak and again in October, trunk diameter $15.0 \mathrm{~cm}$ above soil level was measured on each tree. For each speciestreatment combination, trunk diameter increase (difference between fall and spring measurements) was averaged for three trees. Ten randomly selected shoots on each tree were selected in the spring of each year and shoot elongation (based upon growth from bud scales to the terminal bud) was measured in late fall. Shoot elongation was averaged for each species-treatment combination (mean of 30 shoots). Leaf area was determined by defoliating all trees. A subsample of 20 leaves was randomly selected from each tree and subsample leaf area was measured with a leaf area meter (model CI-203 with CI-203A conveyor attachment; CID, Vancouver, Wash.). To obtain total foliage dry weight for each tree, all leaves were dried at $60^{\circ} \mathrm{C}$ for 1 week. Subsample leaf areas : dry weight ratios were multiplied by the dry weight of the all leaves to estimate total leaf area for each tree. Leaf size for each species-treatment combination was averaged for 60 leaves. For each species-treatment combination, total leaf area

Predawn $\psi_{\mathrm{L}}$ for each species was plotted against weeks after transplanting (WAT) in 1995 and 1996. Because of similarities among sampling dates, morning-to-evening data from 21 July 1995 and 29 Aug. 1996 and midday Pn and $g_{\mathrm{s}}$ from 30 Aug. 1995 and 22 Aug. 1996 are presented as representative for all sample dates. S $\downarrow$, TA, RH, $g_{\mathrm{s}}$, and LVPD for 21 July 1995 and 29 Aug. 1996 were plotted against time of day. To examine the effect of $S \downarrow, T A$, $\mathrm{TL}, \psi_{\mathrm{L}}$, and RH (independent variables) on $g_{\mathrm{s}}$ (dependent variable), $g_{\mathrm{s}}$ data were analyzed with the stepwise regression procedure of SAS (SAS Inst., 1996) using appropriate means. A linear curve was selected according to significance of each variable and the value of $R^{2}$. The response of $g_{\mathrm{s}}$ to LVPD was also examined. Stomatal conductance (dependent variable) and LVPD (independent variable) data were analyzed in SAS by regression analysis, and linear or quadratic curves were selected according to significance of the equation and the value of $R^{2}$. Means for predawn $\psi_{\mathrm{L}}, g_{\mathrm{s}}$, and LVPD cycles (treatment means for each species and each cycle throughout each day measurements were taken), midday $\operatorname{Pn}$ and $g_{s}$, and all growth data were analyzed in SAS based on a completely randomized design. If significant differences were found, means were separated by Fisher's least significance difference procedure $(P \leq 0.05)$.

\section{Results and Discussion}

All trees survived transplanting. Predawn $\psi_{\mathrm{L}}$ data from 1995 indicate that following transplanting, transplanted trees were under was averaged for three trees.

greater water deficit stress (more negative $\psi_{\mathrm{L}}$ ) than were control trees (Fig. 1). Through early Aug. 1995 (17 WAT), predawn $\psi_{\mathrm{L}}$ for controls ranged from -0.2 to $-0.4 \mathrm{MPa}$, whereas the range for transplanted trees was -0.6 to -1.9 MPa. In mid-Aug. 1995 (18 WAT), predawn $\psi_{\mathrm{L}}$ for transplanted maple trees recovered to levels similar to those of control trees and remained there most of the remaining growing season. Predawn $\psi_{\mathrm{L}}$ for transplanted linden trees also recovered to levels near those of controls by 18 WAT, but remained more negative for most of the remaining season. Data for both species in the 1996 growing season were similar to those obtained in late 1995 (Fig. 1).

Our results are similar to those of others who have compared $\psi_{\mathrm{L}}$ and shoot water potential $\left(\psi_{\mathrm{S}}\right)$ of transplanted and control, FG trees. Kjelgren and Cleveland (1994) found that nonirrigated, transplanted, FG silver maple (Acer saccharinum L.) and Kentucky coffee (Gymnocladus dioicus Lam.) trees grown in Illinois required 13 weeks and two growing seasons, respectively, to recover to control predawn $\psi_{\mathrm{L}}$ levels. Predawn fascicle water potential of transplanted, FG slash pine (Pinus elliottii Engelm.) trees in Florida (irrigated every day with $35.0 \mathrm{~L}$ of water) recovered to control levels 6 WAT (Beeson and Gilman, 1992). Also in Florida, Gilman and Beeson (1996) observed $\psi_{\mathrm{s}}$ for transplanted, FG laurel oak (Quercus laurifolia Michx.) and 'East Palatka' holly (Ilex $\times$ attenuata Ash.) irrigated with 40 L every day the first 14 WAT and 60 $\mathrm{L}$ every other day thereafter. They reported that $\psi_{\mathrm{S}}$ of transplanted trees did not recover to control levels until between 15 and 40 WAT.

As was the case in our study, water deficit

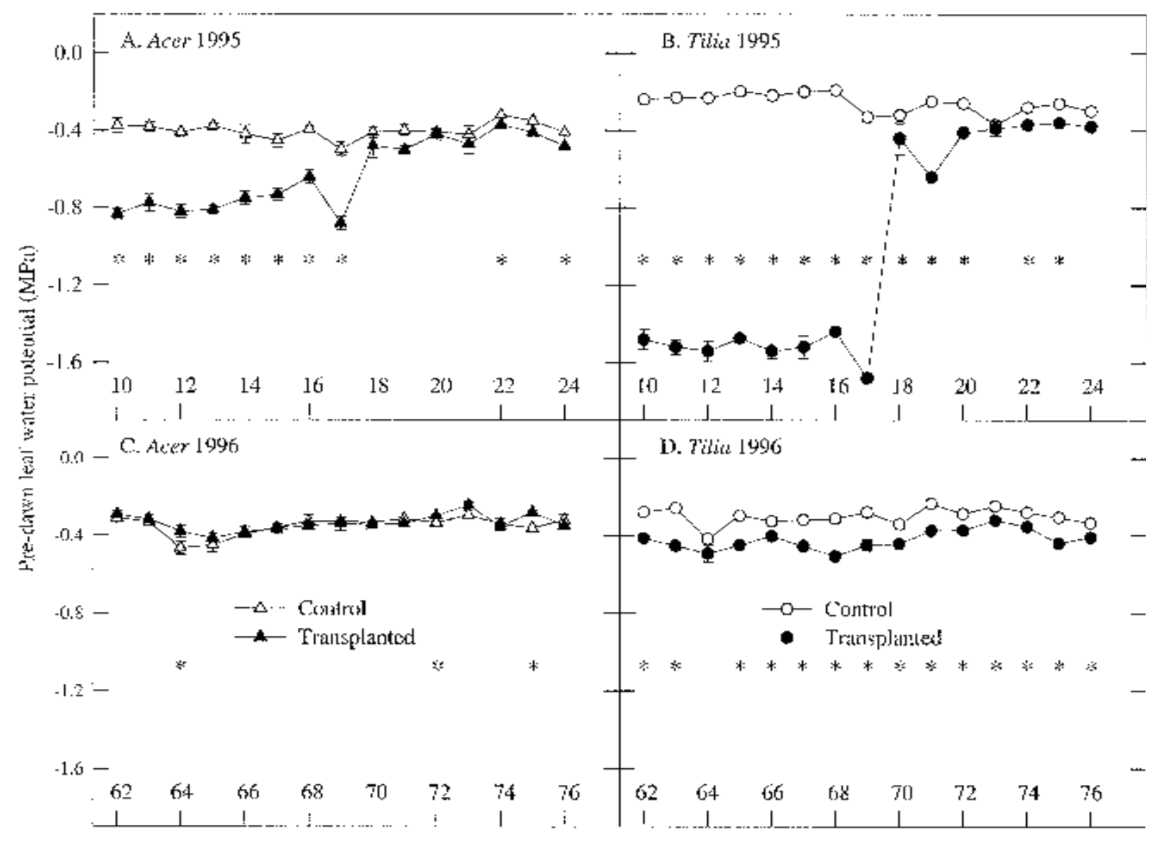

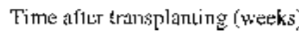

Fig. 1. Effects of transplanting on predawn leaf water potential in Norway maple (Acer platanoides 'Schwedleri') and littleleaf linden (Tilia cordata 'Greenspire') trees in 1995 (A, B) and 1996 (C, D) Each point is the mean of six measurements. Asterisks indicate significant effects of transplanting at the $1 \%, 5 \%$, or $10 \%$ level by $\mathrm{F}$ test. Vertical bars represent standard errors (SE) of the mean. SE is smaller than symbol when vertical bar is not shown. 
stress often develops when FG trees are placed into landscapes (Kozlowski and Davies, 1975). High transpiration rates can cause rapid drying of the root ball (Watson and Kupkowski, 1991) and lead to deficit moisture stress. For transplanted, FG trees, new root growth originates primarily from the ends of severed roots (Watson and Himelick, 1982) and can take up to 7 weeks to begin (Arnold and Struve, 1989; Bevington and Castle, 1985). Moisture outside of the root ball is therefore unavailable to the tree (Gilman, 1988), and water uptake by the root ball must occur through older, suberized roots (Kramer and Kozlowski, 1979). Until new roots grow into the surrounding soil the tree is likely to be subjected to water deficit stress (Watson and Kupkowski, 1991). Research by Abod and Webster (1991b), and Watson and Himelick (1982), confirms that new roots of transplanted Norway maple regenerate soon after transplanting, while new roots of littleleaf linden are slow to initiate. Because the restoration of a transplanted tree's water balance is associated with root regeneration (Hallman et al., 1978; Kramer, 1987), the more rapid recovery of transplanted maple to control predawn $\psi_{\mathrm{L}}$ was probably due to more rapid root growth.

In 1995 and 1996, trends in morning-toevening LVPD and $g_{s}$ and midday Pn and $g_{s}$ values were similar to trends in predawn $\psi_{\mathrm{L}}$ data. Weather for 21 July 1995 and 29 Aug. 1996 was typical for summer days in northern Utah (Fig. 2) and was representative of the other sample dates. TA ranged from $15^{\circ} \mathrm{C}$ in the morning to near $29^{\circ} \mathrm{C}$ in the afternoon. $\mathrm{RH}$ dropped to $\approx 25 \%$ during the afternoon after beginning each day over $60 \%$. S $\downarrow$ data indicate that each day was mostly sunny, but that there was early morning cloud cover on 21 July 1995 . Weather for days when midday Pn was measured was similar to days when morning-to-evening $g_{\mathrm{s}}$ was taken (data not shown).

Morning-to-evening $g_{\mathrm{s}}$ data from 1995 indicate that $g_{\mathrm{s}}$ of control maple trees was 1.5 to 13 times as great, while that of control linden trees was 1.3 to 19.5 times as great as $g_{\mathrm{s}}$ of transplanted trees(Fig. 2). Morning-to-evening data from 1996 show that $g_{s}$ of transplanted maple trees had recovered to control levels, while that of transplanted linden trees remained lower than the $g_{\mathrm{s}}$ of control trees (Fig. 2). On 30 Aug. 1995, midday $g_{\mathrm{s}}$ and Pn values for control maple trees were about twice those of transplanted trees (Fig. 3); $g_{\mathrm{s}}$ for control linden trees was $\approx 2$ times, and Pn was $\approx 4.5$ times the values for transplanted trees. By 22 Aug. 1996, gas exchange measurements for transplanted maple trees did not differ from those of control trees (Fig. 3). However, Pn and $g_{\mathrm{s}}$ for control linden trees remained over two times as great as those of transplanted trees.

For 21 July 1995, LVPD was similar for transplanted and control maple trees until late in the afternoon (Fig. 4). However, LVPD for transplanted linden trees was greater (due to greater $\mathrm{TL}$ ) during most of the day. For each species and treatment, LVPD increased from morning until late in the afternoon. LVPD followed a similar diurnal pattern as on 29
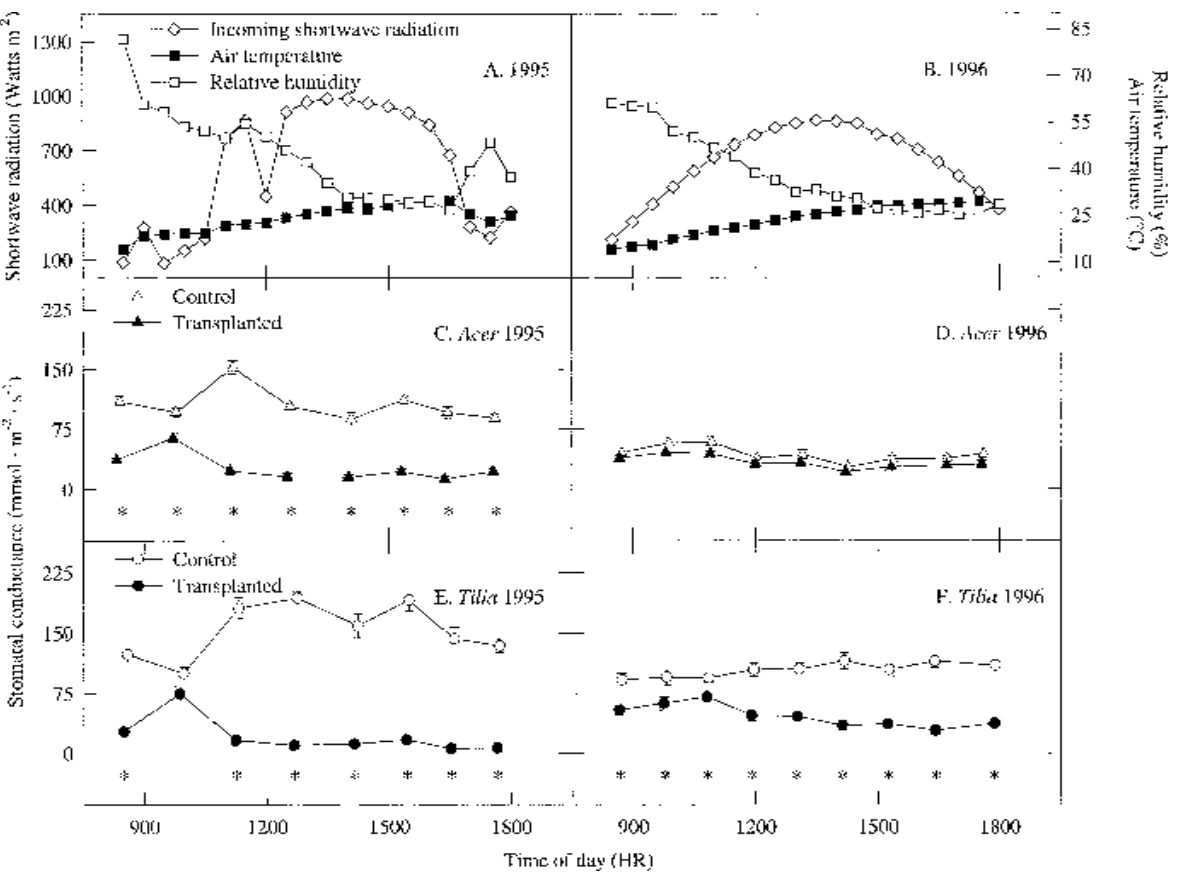

Fig. 2. Incoming shortwave radiation, relative humidity, air temperature $(\mathbf{A}, \mathbf{B})$, and effects of transplanting on stomatal conductance (C-F) of Norway maple (Acer platanoides 'Schwedleri') and littleleaf linden (Tilia cordata 'Greenspire') trees on 21 July 1995 and 29 Aug. 1996. Each point is the mean of 18 measurements. Asterisks indicate significant effects of transplanting at $P \leq 0.05$. Vertical bars represent standard errors (SE) of the mean. SE is smaller than symbol when error bar is not shown.

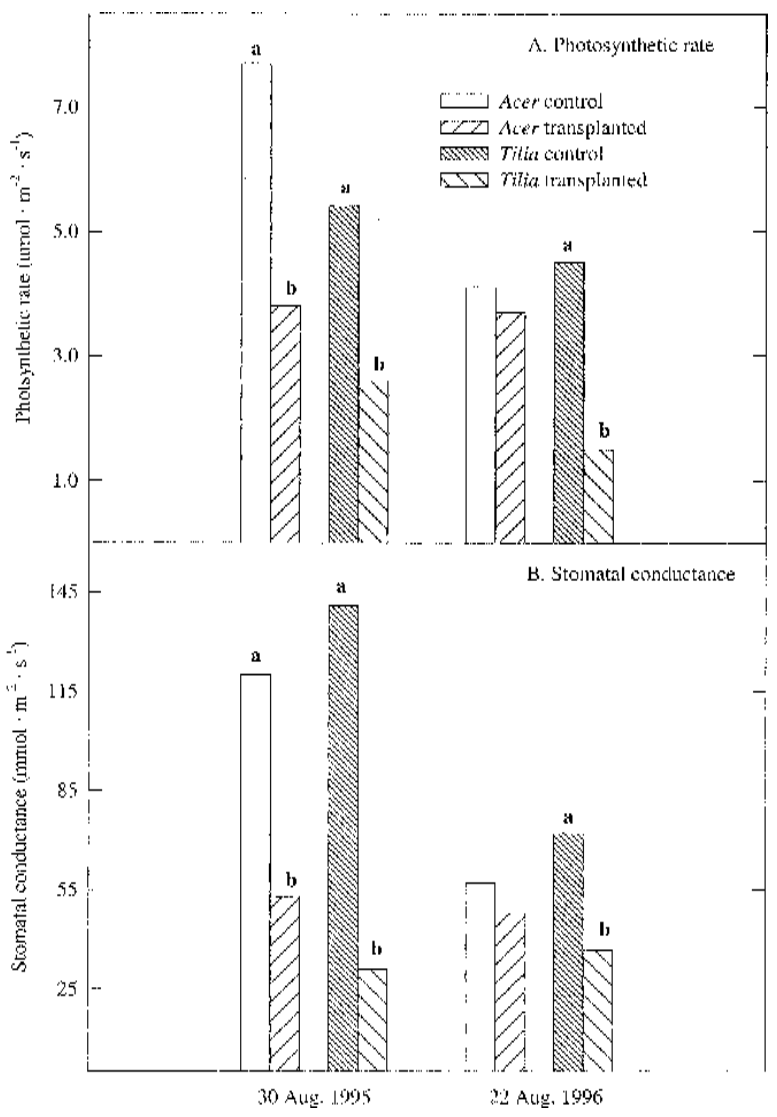

Fig. 3. Effects of transplanting on midday photosynthetic rate (A) and stomatal conductance (B) in Norway maple (Acer platanoides 'Schwedleri') and littleleaf linden (Tilia cordata 'Greenspire') trees on 30 Aug. 1995 and 22 Aug. 1996. Each bar is the mean of 27 measurements. Different letters indicate significant effects of transplanting at $P \leq 0.05$. 
Aug. 1996 (Fig. 4). During most of the day, LVPD was similar for transplanted and control maple trees, but was generally lower for control linden trees than for transplanted linden trees. Stepwise regression of the response of $g_{\mathrm{s}}$ to climatic data revealed the following equation: $g_{\mathrm{s}}=(27.2)+(0.06 \mathrm{~S} \downarrow)+$ $(5.3 \mathrm{TA})-(39.8 \mathrm{LVPD})-\left(3.6 \psi_{\mathrm{L}}\right)$. The $R^{2}$ value for the equation $\left(R^{2}=0.24\right)$ revealed that a more precise equation probably requires additional dependent variables. However, each variable was highly significant $(P \leq 0.0001)$. Each year $g_{\mathrm{s}}$ for transplanted and control maple trees, and transplanted linden trees decreased as LVPD increased (Fig. 5). However, for control linden trees $g_{\mathrm{s}}$ increased with increasing LVPD.

Results from our research are similar to the those of Kjelgren and Cleveland (1994), who reported reduced $g_{\mathrm{s}}$ during the first two growing seasons following transplanting in FG Kentucky coffee tree, but not in transplanted, FG silver maple. They attributed $g_{\mathrm{s}}$ differ- ences in $g_{\mathrm{s}}$ between species to the fibrous root system of silver maple being able to extract more water than the coarse root system of Kentucky coffee tree. Hallman et al. (1978) found that transpiration (E) and Pn rates were reduced in transplanted, FG Scots pine (Pinus sylvestris L.) trees for at least five WAT compared with control trees. Arnold and Struve (1989) found that root pruning green ash trees (Fraxinus pennsylvanica Marsh.) reduced $g_{s}$, $\mathrm{Pn}$, and $\mathrm{E}$ for up to $12 \mathrm{~d}$.

Because of water deficit stress associated with root loss, $g_{\mathrm{s}}$ and Pn were reduced during the first growing season in transplanted trees of both species. However, transplanted maple trees were able to recover to control Pn and $g_{\mathrm{s}}$, apparently because of accelerated root regeneration (Abod and Webster 1991b; Watson and Himelick, 1982) and reduced water deficit stress during the second growing season. For transplanted linden trees, the lack of root development apparently led to continued water deficit stress, which reduced gas exchange

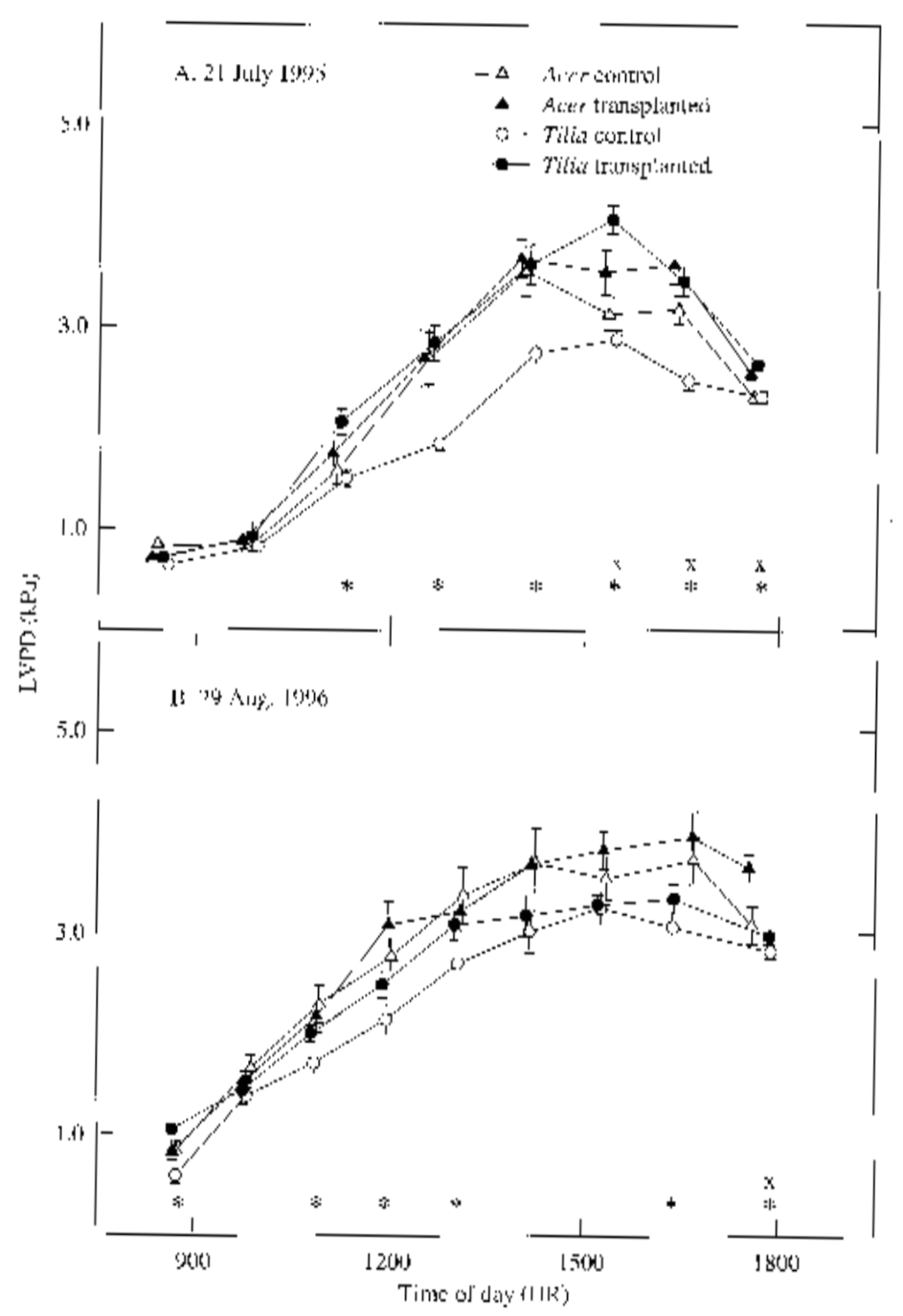

Fig. 4. Effects of transplanting on morning-to-evening leaf-to-air vapor pressure difference (LVPD) in Norway maple (Acer platanoides 'Schwedleri') and littleleaf linden (Tilia cordata 'Greenspire') trees on 21 July 1995 (A) and 29 Aug. 1996 (B). Each point is the mean of 18 measurements. Asterisks (Tilia) or $\mathrm{x}$ (Acer) indicate significant effects of transplanting at the 1\%,5\%, or $10 \%$ level by F test. Vertical bars represent standard errors (SE) of the mean. SE is smaller than symbol when vertical bar is not shown.

throughout both growing seasons (Abod and Webster, 1991b; Witherspoon and Lumis, 1986).

Many plants close their stomata in response to increasing $\mathrm{E}$, thus avoiding desiccation and conserving water (Monteith, 1995; Mott and Parkhurst, 1991). However, when stomata close, growth may be sacrificed because $\mathrm{Pn}$ is reduced (Kozlowski, 1982; Kramer, 1987) and respiration may increase because of higher leaf temperatures (Kramer and Kozlowski, 1979). Sensitivity of stomata to increasing evaporative demand (as indicated by increasing LVPD) varied with species in our study (Fig. 5) and is known to be species-specific (Hinckley et al., 1978; Whitehead et al., 1983). Stepwise regression indicated that $g_{\mathrm{s}}$ was influenced by $\mathrm{S} \downarrow$, TA, and LVPD. Stomatal response to $S \downarrow$ and $\psi_{\mathrm{L}}$ is well documented (Cowan, 1977). However, stomatal response to LVPD (the calculation of which includes $\mathrm{TA}_{\mathrm{A}}$ ) is less well known, especially in ornamental species. From our data, stomata of maple appear to be more sensitive to increasing evaporative demand (increasing LVPD) than are those of linden (Fig. 5). Differences in stomatal sensitivity to LVPD helps to explain the species differences in the daily conductance curves (Fig. 2). Control maple reached its daily $g_{\mathrm{s}}$ maximum early in the day (around $1100 \mathrm{HR}$ for 21 July 1995 and 29 Aug. 1996). However, on both days control linden reached its daily $g_{\mathrm{s}}$ maximum later in the day, when LVPD was greater (Fig. 4).

Stomata for transplanted trees of each species responded similarly to increasing LVPD (Fig. 5). During each study day, $g_{\mathrm{s}}$ was greatest in the morning (when LVPD was lowest) and steadily declined throughout the afternoon (when LVPD was greatest). Stomata of many woody plants close when evaporative demand (due to increasing LVPD) rises above a threshold level (Farquhar, 1978; Turner, et al., 1984). This response to increased evaporative demand (Farquhar, 1978; Mott and Parkhurst, 1991) probably triggered partial stomatal closure (Turner et al., 1984), which reduced $g_{\mathrm{s}}$ in transplanted and control maple and in transplanted linden.

Response of $g_{\mathrm{s}}$ to increasing LVPD differed for transplanted and control linden (Fig. 5). Because TL influences LVPD (Jones, 1992), stomatal response of linden may be partially due to differences in TL. Two factors that can influence TL are E and leaf size. Small leaves tend to dissipate heat more readily than do larger leaves (Campbell, 1977), and leaves with high $\mathrm{E}$ (due to high $g_{\mathrm{s}}$ ) dissipate more energy through greater evaporative cooling than do those with low E (Jones, 1992). In our study, control linden trees had larger leaves (Table 1), but greater $g_{\mathrm{s}}$ rates for each study day (Fig. 2) than did control trees. High $g_{s}$ reduced TL (which lowered LVPD) throughout each day (data not shown). For control linden, high $g_{s}$ and low TL appear to have lowered LVPD such that a threshold LVPD level was not reached. Increased $g_{\mathrm{s}}$ in response to increased LVPD has been reported for several species (Andersen and Brodbeck, 1988; Marshall and Waring, 1984), and may be an 


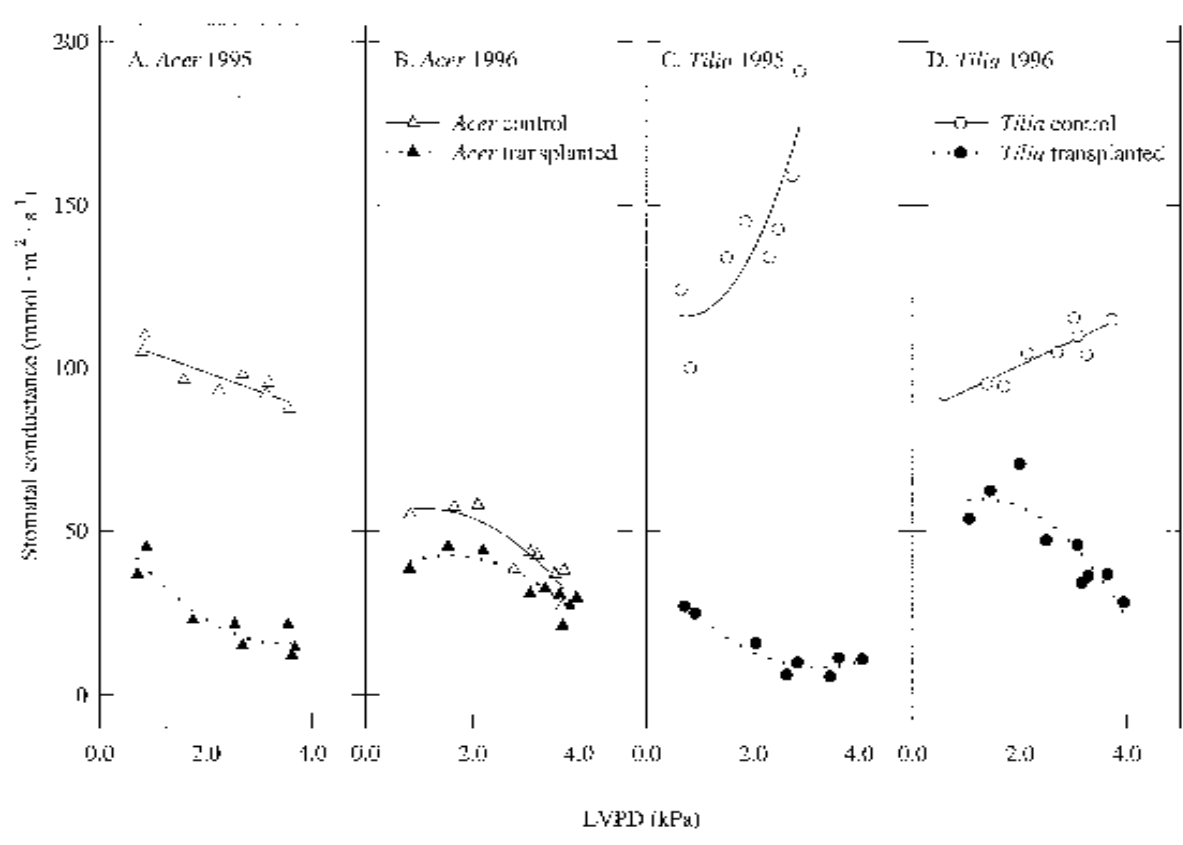

Fig. 5. Effects of transplanting on actual and predicted values for the influence of leaf-to-air vapor pressure difference (LVPD) on stomatal conductance $\left(g_{\mathrm{s}}\right)$ in Norway maple (Acer platanoides 'Schwedleri') and littleleaf linden (Tilia cordata 'Greenspire') trees on 21 July 1995 and 29 Aug. 1996. Each point is the mean of 18 measurements. Predicted regression line equations are followed by $R^{2}$ values and significance for the equation: 21 July 1995 control A. platanoides $(\mathbf{A}): g_{\mathrm{s}}=110.3-5.8 \mathrm{x}, R^{2}=0.75$ $P=0.005 ; 21$ July 1995 transplanted A. platanoides $(\mathbf{A}): g_{\mathrm{s}}=56.6-23.7 \mathrm{x}+3.4 \mathrm{x}^{2}, R^{2}=0.85, P=0.086$; 29 Aug. 1996 control A. platanoides $(\mathbf{B}): g_{\mathrm{s}}=52.3+8.1 \mathrm{x}-3.6 \mathrm{x}^{2}, R^{2}=0.81, P=0.007 ; 29$ Aug. 1996 transplanted A. platanoides $(\mathbf{B}): g_{\mathrm{s}}=34.5+10.1 \mathrm{x}-3.2 \mathrm{x}^{2}, R^{2}=0.76, P=0.013 ; 21$ July 1995 control T. cordata $(\mathbf{C}): g_{\mathrm{s}}=123.1-19.1 \mathrm{x}+12.8 \mathrm{x}^{2}, R^{2}=0.74, P=0.032 ; 21$ July 1995 transplanted $T$. cordata (C): $g_{\mathrm{s}}=40.1-19.5 \mathrm{x}+3.0 \mathrm{x}^{2}, R^{2}=0.92, P=0.002 ; 29$ Aug. control $T$. cordata $(\mathbf{D}): g_{\mathrm{s}}=85.6+7.7 \mathrm{x}$ $R^{2}=0.80, P=0.001 ; 29$ Aug. 1996 transplanted $T$. cordata $(\mathbf{D}): g_{\mathrm{s}}=50.9+13.4 \mathrm{x}-5.0 \mathrm{x}^{2}, R^{2}=0.76$, $P=0.012$

Table 1. Effects of transplanting on stem area increase, shoot elongation, average leaf size, and total leaf area in Norway maple (Acer platanoides 'Schwedleri') and littleleaf linden (Tilia cordata 'Greenspire') trees in 1995 and 1996.

\begin{tabular}{|c|c|c|c|c|c|c|c|c|}
\hline \multirow[b]{3}{*}{ Variable } & \multicolumn{4}{|c|}{ Acer platanoides } & \multicolumn{4}{|c|}{ Tilia cordata } \\
\hline & \multicolumn{2}{|c|}{1995} & \multicolumn{2}{|c|}{1996} & \multicolumn{2}{|c|}{1995} & \multicolumn{2}{|c|}{1996} \\
\hline & Trans $^{z}$ & Control & Trans & Control & Trans & Control & Trans & Control \\
\hline Stem area increase $\left(\mathrm{cm}^{2}\right)$ & $0.5 \mathrm{~b}^{\mathrm{y}}$ & $10.3 \mathrm{a}$ & $3.3 \mathrm{~b}$ & $15.8 \mathrm{a}$ & $0.2 \mathrm{~b}^{\mathrm{y}}$ & $8.9 \mathrm{a}$ & $1.4 \mathrm{~b}$ & $\overline{7.0 \mathrm{a}}$ \\
\hline Shoot elongation $(\mathrm{cm})$ & $5.9 \mathrm{~b}$ & $11.1 \mathrm{a}$ & $2.7 \mathrm{~b}$ & $13.7 \mathrm{a}$ & $4.4 \mathrm{~b}$ & $12.7 \mathrm{a}$ & $3.1 \mathrm{~b}$ & $15.2 \mathrm{a}$ \\
\hline Leaf size $\left(\mathrm{cm}^{2}\right)$ & $39.6 \mathrm{~b}$ & $70.8 \mathrm{a}$ & $60.3 \mathrm{~b}$ & $89.5 \mathrm{a}$ & $14.5 \mathrm{~b}$ & $30.4 \mathrm{a}$ & $16.6 \mathrm{~b}$ & $36.6 \mathrm{a}$ \\
\hline Total leaf area $\left(\mathrm{m}^{2}\right)$ & $5.6 \mathrm{~b}$ & $11.3 \mathrm{a}$ & $5.5 \mathrm{~b}$ & $16.8 \mathrm{a}$ & $2.4 \mathrm{~b}$ & $6.5 \mathrm{a}$ & $2.8 \mathrm{~b}$ & $7.3 \mathrm{a}$ \\
\hline \multicolumn{9}{|c|}{ Significance } \\
\hline Stem area increase $\mathrm{e}^{\mathrm{x}}$ & \multicolumn{2}{|c|}{0.0003} & \multicolumn{2}{|c|}{0.0008} & \multicolumn{2}{|c|}{0.002} & \multicolumn{2}{|c|}{0.002} \\
\hline Shoot elongation ${ }^{w}$ & \multicolumn{2}{|c|}{0.09} & \multicolumn{2}{|c|}{0.01} & \multicolumn{2}{|c|}{0.002} & \multicolumn{2}{|c|}{0.0001} \\
\hline Average leaf size $\mathrm{v}^{\mathrm{v}}$ & \multicolumn{2}{|c|}{0.002} & \multicolumn{2}{|c|}{0.02} & \multicolumn{2}{|c|}{0.0001} & \multicolumn{2}{|c|}{0.0008} \\
\hline Total leaf area ${ }^{x}$ & \multicolumn{2}{|c|}{0.05} & \multicolumn{2}{|c|}{0.03} & \multicolumn{2}{|c|}{0.0005} & \multicolumn{2}{|c|}{0.002} \\
\hline
\end{tabular}

${ }^{2}$ Transplanted.

${ }^{y}$ Mean seperation within rows, species, and years by LSD, $P \leq 0.05$.

${ }^{x} \mathrm{n}=3$.

${ }^{\mathrm{w}} \mathrm{n}=30$.

$\mathrm{v} n=60$.

adaptation to maximize Pn in environments where soil water is nonlimiting (El-Sharkawy and Cock, 1984; Marshall and Waring, 1984).

Data from two growing seasons indicated that growth was substantially reduced by transplanting. Stem area increase in 1995 in control maple and linden was 20 and 44 times as great, respectively, as in transplanted trees (Table 1). In 1996, stem area of control trees of each species was five times as great as that of transplanted trees. For transplanted trees, shoot size followed a similar trend in 1996.

Apical growth of transplanted trees was probably reduced by several factors. Each tree species has a specific root : shoot ratio for optimum growth (Kramer and Kozlowski, 1979). If this ratio is altered (by transplanting or pruning) assimilates are redirected to replace removed tissue (Gilman, 1992). Because trees in our study lost a significant portion of their root system, vigorous top growth did not occur until the species-specific root : shoot ratio was restored (Geisler and Ferree, 1984; Gilman, 1992). Reduced leaf area also limited carbon assimilation by reducing photosynthetic capability. Water deficit stress can also limit apical growth of trees by reducing mineral uptake and assimilation, hormone synthesis, stomatal conductance, and photosynthesis (Geisler and Ferree, 1984; Kuhns and Gjerstad, 1988).

Criteria that have been used to determine when transplanted trees become established are recovery of $\psi_{\mathrm{L}}$, gas exchange, and growth rates (Beeson and Gilman, 1992; Watson, 1985). Using these parameters, transplanted, FG trees in our study were not established after two growing seasons. Tree species differ in sensitivity to transplanting stress (Abod and Webster, 1991a). In our study, water deficit stress, brought on by transplanting, reduced gas exchange and growth the first year after transplanting. However, during the second season, transplanted maple trees recovered to control predawn $\psi_{\mathrm{L}}$ levels; therefore, gas exchange was not influenced by water deficit stress, but by response of stomata to high evaporative demand (Farquhar, 1978; Mott and Parkhurst, 1991). For transplanted linden trees, a combination of water deficit stress and stomatal response to high evaporative demand during the second growing season reduced gas exchange and prevented recovery to control gas exchange levels.

Our research indicates that in an arid climate with limited irrigation, transplanted, FG maple trees are able to reach control gas exchange levels more rapidly, and possibly become established sooner, than are transplanted, FG linden trees of similar trunk diameter. However, after two growing seasons neither tree species had recovered to control apical growth rates. Arborists, landscape contractors, and horticulturists working with transplanted, FG trees should be aware that the time required for trees to become established may be longer in arid climates with limited irrigation than in more mesic, humid climates. When transplanting FG trees in arid regions with limited irrigawhile leaves of control maples were $78 \%$ larger than in transplant trees. Total leaf area for transplanted trees was less than half of control (Table 1). Total tree leaf area and leaf tion, precautions must be taken to ensure tree survival. Planting species that establish rapidly under these conditions should increase survival and save expenses associated with maintenance or replacement.

\section{Literature Cited} trees was twice that of transplanted trees,

elongation was less in 1995 than for control trees (Table 1). In 1996, shoot elongation for transplanted trees was $\approx 20 \%$ that of contro trees. Leaf size and total leaf area for transplanted trees were less than for control trees in

Abod, S.A. and A.D. Webster. 1991a. The influence of root pruning on subsequent root and shoot growth of Malus, Tilia, and Betula. J. Hort. Sci. 66:227-233. 
Abod, S.A. and A.D. Webster. 1991b. Carbohydrates and their effects on growth and establishment of Tilia and Betula: I. Seasonal changes in soluble and insoluble carbohydrates. J. Hort. Sci. 66:235-246.

American Standard for Nursery Stock. 1990. ANSI Z60.1-1990. Amer. Assn. Nurserymen, Washington, D.C.

Andersen, P.C. and B.V. Brodbeck. 1988. Net $\mathrm{CO}_{2}$ assimilation and plant water relations characteristics of pecan growth flushes. J. Amer. Soc. Hort. Sci. 113:444-450.

Arnold, M.A. and D.K. Struve. 1989. Green ash establishment following transplant. J. Amer. Soc. Hort. Sci. 114:591-595.

Beeson, R.C. and E.F. Gilman. 1992. Diurnal water stress during landscape establishment of slash pine differs among three production methods. J. Arboricult. 18:281-287.

Bevington, K.B. and W.S. Castle. 1985. Annual root growth pattern of young citrus trees in relation to shoot growth, soil temperature, and soil water content. J. Amer. Soc. Hort. Sci. 110:840-845.

Campbell, G.S. 1977. An introduction to environmental biophysics. Springer-Verlag, New York.

Cowan, I.R. 1977. Stomatal behaviour and environment, p. 117-228. In: R.D. Preston and H.W. Woolhouse (eds.). Advances in botanical research. 4th ed. Academic, London.

El-Sharkawy, M.A. and J.H. Cock. 1984. Water use efficiency of cassava. I. Effects of air, humidity, and water stress on stomatal conductance and gas exchange. Crop Sci. 24:497-502.

Farquhar, G.D. 1978. Feedforward responses of stomata to humidity. Aust. J. Plant Physiol. 5:787-800

Geisler, D. and D.C. Ferree. 1984. The influence of root pruning on water relations, net photosynthesis, and growth of young 'Golden Delicious' apple trees. J. Amer. Soc. Hort. Sci. 109:827-831.

Gilman, E.F. 1988. Tree root spread in relation to branch dripline and harvestable root ball. HortScience 23:251-253.

Gilman, E.F. 1992. Effect of root pruning prior to transplanting on establishment of southern magnolia in the landscape. J. Arboricult. 18:197200

Gilman, E.F. and R.C. Beeson. 1996. Production method affects tree establishment in the landscape. J. Environ. Hort. 14:81-87.

Hallman, E., P. Hari, P.K. Rasanen, and H. Smolander. 1978. Effect of planting shock on the transpiration, photosynthesis, and height increment of Scots pine seedlings. Acta For. Fennica 161:1-23.

Harris, J.R. and E.F. Gilman. 1993. Production method affects growth and post-transplant establishment of 'East Palatka' holly. J. Amer. Soc. Hort. Sci. 118:194-200.

Harris, J.R., P. Knight, and J. Fanelli. 1998. Effect of root severance on growth of field-grown sugar maple. HortScience 33:21-23.

Hinckley, T.M., R.G. Aslin, R.R. Aubuchon, C.L. Metcalf, and J.E. Roberts. 1978. Leaf conductance and photosynthesis in four species of the oak-hickory forest type. For. Sci. 24:73-84.

Jones, H.G. 1992. Plants and microclimate: A quantitative approach to environmental plant physiology. 2nd ed. Cambridge Univ. Press, Cambridge.

Karlic, H. and H. Richter. 1979. Storage of detached leaves and twigs without changes in water potential. New Phytol. 83:379-384.

Kjelgren, R. and B. Cleveland. 1994. Growth and water relations of Kentucky coffee tree and silver maple following transplanting. J. Environ. Hort. 12:96-99.

Kozlowski, T.T. 1982. Water supply and tree growth. I. Water deficits. For. Abstr. 43:57-95.

Kozlowski, T.T. and W.J. Davies. 1975. Control of water balance in transplanted trees. J. Arboricult. $1: 1-10$.

Kramer, P.J. 1987. The role of water stress in tree growth. J. Arboricult. 13:33-38.

Kramer, P.J. and T.T. Kozlowski. 1979. Physiology of woody plants. Academic Press, New York.

Kuhns, M.R. and D.H. Gjerstad. 1988. Photosynthate allocation in loblolly pine (Pinus taeda) seedlings as affected by moisture stress. Can. J. For. Res. 18:285-291.

Marshall, J.D. and R.H. Waring. 1984. Conifers and broadleaf species: Stomatal sensitivity differs in western Oregon. Can. J. For. Res. 14:905-908.

Mitchell, C.A. 1992. Measurement of photosynthetic gas exchange in controlled environments. HortScience 27:764-767.

Monteith, J.L. 1995. A reinterpretation of stomatal responses to humidity. Plant, Cell Environ. 18:357-364.

Mott., K.A. and D.F. Parkhurst. 1991. Stomatal responses to humidity in air and helox. Plant, Cell Environ. 14:509-515.

SAS Institute, 1996. SAS ver. 6.12. SAS Inst., Cary, N.C.

Scheoneweiss, D.F. 1981. Infectious diseases of trees associated with water and freezing stress. J. Arboricult. 7:13-18.

Turner, N.C., E.D. Schulze, and T. Gollan. 1984. The responses of stomata and leaf gas exchange to vapour pressure deficits and soil water content. I. Species comparisons at high soil water contents. Oecologia 63:338-342.

Watson, G. 1985. Tree size affects root regeneration and top growth after transplanting. J. Arboricult 11:37-40.

Watson, G.W. and E.B. Himelick. 1982. Seasonal variation in root regeneration of transplanted trees. J. Arboricult. 8:305-310.

Watson, G.W., E.B. Himelick, and E.T. Smiley. 1986. Twig growth of eight species of shade trees following transplanting. J. Arboricult. 12:241-245.

Watson, G.W. and G. Kupkowski. 1991. Soil moisture uptake by green ash trees after transplanting. J. Environ. Hort. 9:227-230.

Watson, G.W. and T.C. Sydnor. 1987. The effect of root pruning on the root system of nursery trees. J. Arboricult. 13:126-130.

Whitehead, D., D.W. Sheriff, and D.H. Greer. 1983. The relationship between stomatal conductance, transpiration rate and tracheid structure in Pinus radiata clones grown at different water vapour saturation deficits. Plant, Cell Environ. 6:703710.

Witherspoon, W.R. and G.P. Lumis. 1986. Root regeneration, starch content, and root promoting activity in Tilia cordata cultivars at three different digging-planting times. J. Environ. Hort. 4:7679. 